Ibn Al-Haitham Jour. for Pure \& Appl. Sci. 33 (4) 2020

Ibn Al Haitham Journal for Pure and Applied Science

Journal homepage: http://jih.uobaghdad.edu.iq/index.php/j/index

\title{
Study of Lung Cancer Hazard Due to Radiate Radon Gas for Two Factories in Industrial Region (Shaikh Omar) of Baghdad Governorate
}

\author{
N. A. Mohammed \\ Ministry of Education, Directorate \\ General of Education Rusafa3, \\ Baghdad, Iraq \\ noorphysics1@gmail.com
}

\author{
S.A.Ebrahiem \\ Department of Physics, College of \\ Education for Pure Sciences Ibn Al- \\ Haitham , University of Baghdad, \\ .Baghdad, Iraq \\ samaeb85@gmail.com
}

Article history: Received 25 December 2020, Accepted 20 February 2020, Published October 2020.

Doi: $10.30526 / 33.4 .2522$

\begin{abstract}
During the winter, in the industry region (Shaikh Omer) and by applying a passive radon detector (CR-39), lung cancer risk has been measured in twelve rooms of different workshops of two old factories in this site. The radon concentration is ranged from $\left(123.345 \mathrm{~Bq} / \mathrm{m}^{3}\right)$ to $\left(328.985 \mathrm{~Bq} / \mathrm{m}^{3}\right)$ with an average of $\left(244.19 \pm 61.52 \mathrm{~Bq} / \mathrm{m}^{3}\right)$. Lung cancer risk ranged from 55.993 to 149.346 per million people and with an average of (110.855 per million people) which were lower than the recommended values (170-230 per million people), so there was no cancer risk on workers in these locations.
\end{abstract}

Keyword: Radon decay, radon risk parameters, Shaikh Omer region.

\section{Introduction}

Radon is found in all types of soils and rocks in concentration that varies from region to region and during the seasons. when gas is sent out from the soil, it spreads in the open air at small speed and safe due to its half-life. Once it infiltrates into closed places,it can pile, and reach to dangerous levels relying on its concentration in soil, buildings materials. It can enter the buildings through groundwater or from the building materials that have Radium[1].when the radiation enters the lung, it decays inside it, which is the subject? save for a few amounts transported by blood. The risk of radon begins from the fact that when it decays, that it's solid decays products settle in the airways and inner surfaces of the lung. The decays products of 
Ibn Al-Haitham Jour. for Pure \& Appl. Sci. 33 (4) 2020

radon are polonium $\left({ }^{218} \mathrm{Po}\right)$, half-life $\left(\mathrm{t}_{1 / 2}=3.05 \mathrm{~min}\right)$, which end with the lead $\left({ }^{214} \mathrm{~Pb}\right)$, halflife $\left(\mathrm{t}_{1 / 2}=26.8 \mathrm{~min}\right)$, then Bismuth $\left({ }^{214} \mathrm{Bi}\right)$ the half-life of it $\left(\mathrm{t}_{1 / 2}=19.7 \mathrm{~min}\right)$ down to polonium $\left({ }^{214} \mathrm{Po}\right)$ which has half-life $\left(\mathrm{t}_{1 / 2}=162 \mu \mathrm{s}\right)$. Two of these products are emitters of alpha particles $\left({ }^{218} \mathrm{Po}\right.$ emitter alpha at energy $6 \mathrm{MeV}$ and ${ }^{214} \mathrm{Po}$ emitter alpha at energy $\left.7.69 \mathrm{MeV}\right)$, which are the main source of harmful radiation if they stabilize within the lung[2].The danger of lung cancer from exposure of the Radon and its decay outputs depend on their concentration level in the home; also the extent of time that a person ;is exposed to Radon exporter and whether the human is a smoker. Radon, that comes from the materials in floors, ceiling, and walls can grant rise to increase the concentrations of indoor Radon. The size of Radon emission from different portions of the building relies on the concentration of Radium in the building material, also the materials humidity, permeability, and porosity, furthermore the thickness of the wall [3]

\section{Description of Study Area}

Shaikh Omar region as shown in figure (1), is an old industrial area located on the side of Rusafa and specializes in the availability and repair of car equipment and is one of the most important industrial areas in Baghdad, including a number of factories, workshops that contain many types of metals, tools and equipment for work such as Computer Numerically Controlled (CNC) which is electro-mechanical device used to design several tools of metal.

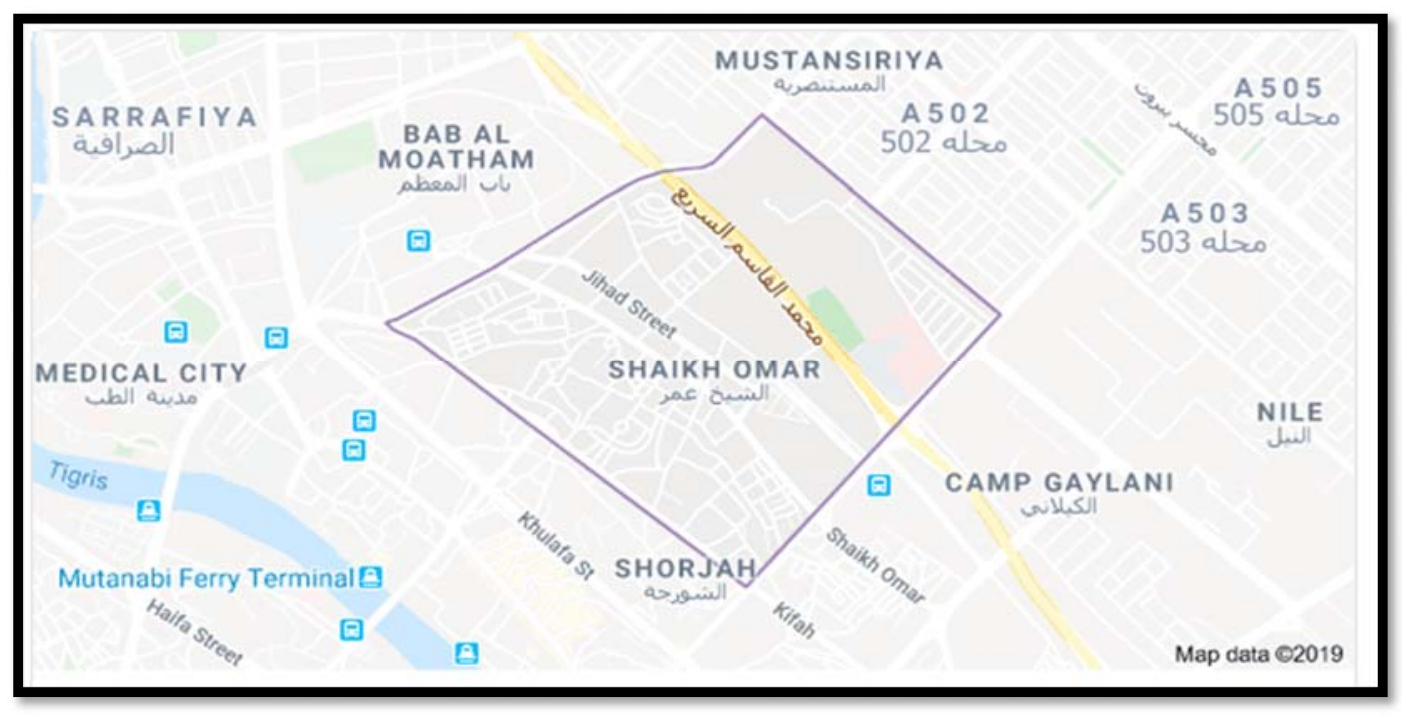

Figure 1. Shaikh Omar location in Baghdad governorate

\section{Experimental}

Two factories dating to 1930 s were chosen to monitor in the industrial region (Shaikh Omar) which had many workers who where spending spend long periods in these places (7 Am to $3 \mathrm{Pm}$ ). It was, therefore, necessary to recognize the radiation levels and their health effects to ensure the safety of the worker. Twelve rooms were chosen randomly, which belong to different workshops that contained different types of metals and machines needed for their work. This study was done using, Solid-state nuclear detectors type CR-39 which distributed inside study positions in different numbers, and at a height of $150 \mathrm{~cm}$ from the ground level. After an exposure time of 30 days, the parts of the detector was collected, and chemically etched by using $\mathrm{NaOH}$ at $60^{\circ} \mathrm{C}$ for 4.5 hours; the traces of alpha damage per unit area were 


\section{Ibn Al-Haitham Jour. for Pure \& Appl. Sci. 33 (4) 2020}

counted using an optical microscope with a magnification of 400X. Figure (2) shows the calibration curve between the exposure of radon (Es) and the track density $\left(\rho_{s}\right)$ in unit tracks $/ \mathrm{mm}^{2}$ of the standard source $\left({ }^{226} \mathrm{Ra}\right)$ with an activity of $181692 \mathrm{~Bq}$. The concentration of Radon in the air (CRM) in the samples was calculated by the following relation [4].

$\mathrm{C}_{\mathrm{Rn}}=\frac{\mathrm{E}_{s}}{\rho_{s}} \times \frac{\rho_{x}}{\mathrm{t}}$

Where : $\left(\mathrm{C}_{\mathrm{Rn}}\right)$, represents the concentration of Radon in the air $\left(\mathrm{Bq} / \mathrm{m}^{3}\right)$.

$\frac{\mathrm{E}_{S}}{\rho_{s}}=$ slope, that represents the calibration factor and it is obtained from the linear calibration curve in figure (2).

$\left(\rho_{x}\right)$ indicates to tracks density (in unit tracks $/ \mathrm{mm}^{2}$ ) from radon exposure inside the location which was calculated by dividing the average number of tracks per detector (10 readings were counted of each detector) by the area of the square $\left(0.07 \mathrm{~mm}^{2}\right)$.

(t) Symbolizes the time of exposure (30 days).

UNSCEAR2000 reports (United Nations Scientific Committee on the Effects of Atomic Radiation) consider that radon contributes $55 \%$ of the average annual dose per capita from natural sources. Continued exposure to radon at high concentrations can lead to lung cancer. is in allowable level at $150 \mathrm{~Bq} / \mathrm{m}^{3}$ in new buildings and $200 \mathrm{~Bq} / \mathrm{m}^{3}$ in old buildings[5]. After obtaining the radon concentrations, it can deduce the lung cancer with anther risk parameters as follow:

1. The Annual Effective Dose (AED) has been measured in a unit of $(\mathrm{mSv} / \mathrm{y})$ as follow: $[6,7]$

$\operatorname{AED}\left(\mathrm{mSv} \cdot \mathrm{y}^{-1}\right)=\mathrm{C}_{\mathrm{Rn}} \times \mathrm{F} \times \mathrm{H} \times \mathrm{T} \times \mathrm{D}$

Where:

Where: (F) is the operator of equilibrium which is of (0.4) as reports by (UNSCEAR, $2000) ;(H)$ is the factor of occupancy of $(0.8)$, (D) is the transformation factor dose $\left(9 \times 10^{-6}\right.$ $\mathrm{mSv} /\left(\mathrm{Bq} \cdot \mathrm{h} \cdot \mathrm{m}^{3}\right)$, and $(\mathrm{T})$ indicates to hours per year $(8760 \mathrm{~h} / \mathrm{y})$.

2. The Lung Cancer per year per $10^{6}$ people (LCR) has been valuation in the next relation[8]

$\mathrm{LCR}=\mathrm{AED}\left(\mathrm{mSv} \cdot \mathrm{y}^{-1}\right) \times 18 \times 10^{-6}$

3. Exposure to Radon Progeny (EP) was measured as in the following relation: [9]

$\mathrm{EP}_{\mathrm{P}}\left(\mathrm{WLM} \mathrm{Y} \mathrm{Y}^{-1}\right)=8760 * \mathrm{n} * \mathrm{~F} * \mathrm{C}_{\mathrm{Rn}} / 170 * 3700$

Where: $(n)$ represents the fraction of time spent indoors $(0.8),(8760)$ the number of hours per year, and (170) is the number of hours per working month. 
Ibn Al-Haitham Jour. for Pure \& Appl. Sci. 33 (4) 2020

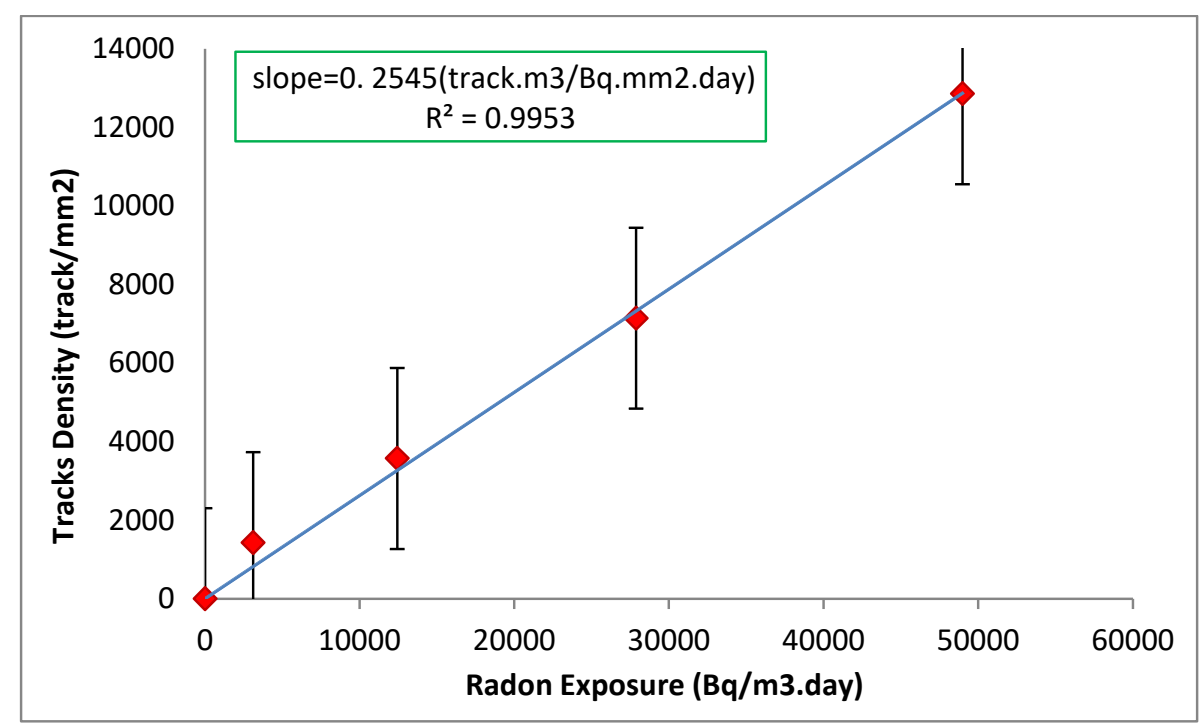

Figure 2. The Calibration Curve for the Radon Exposure (Es) and Track Density (Ps) of Standard Source.

\section{Results and Discussion}

The outcomes of radon concentration for twelve rooms in the two old factories which were calculated using equation (1) with standard deviation(S.D), track density, and rooms dimensions are given in table(1). in this table, it can be noticed that the concentrations of indoor radon ranged from $(123.345 \pm 12.788) \mathrm{Bg} / \mathrm{m}^{3}$ to $(328.985 \pm 46.074) \mathrm{Bg} / \mathrm{m}^{3}$ as shown in figure(3), and most values of radon concentrations have exceeded 200 except for two workshops (P1d and P1g) which had results exceeding $300\left(328.985 \pm 46.074 \mathrm{Bg} / \mathrm{m}^{3}\right.$ and $312.732 \pm 40.517 \mathrm{Bg} / \mathrm{m}^{3}$, respectively), and two other were lower than 200 (P1a and $\mathrm{P} 1 \mathrm{~b}$ ) at values $123.345 \pm 12.788 \mathrm{Bg} / \mathrm{m}^{3}$ and $131.117 \pm 16.569 \mathrm{Bg} / \mathrm{m}^{3}$. back to the $1930 \mathrm{~s}$ and are poorly ventilated, that in these locations several types of chemicals materials Were used as well as different types of metals and equipment that were especial to these workshops. The average value of radon concentration was $244.19 \pm 61.52 \mathrm{Bg} / \mathrm{m}^{3}$ which was within the universally allowed limit $\left(200-300 \mathrm{Bg} / \mathrm{m}^{3}\right)[10]$. The health effects of this gas represented by annual effective dose (AED), lung cancer risk (LCR) per million people and exposure to radon progeny (EP) were listed in table(2). in this table, it can be seen that the values of AED were ranged from $3.110 \mathrm{mSv} / \mathrm{y}$ to $8.297 \mathrm{mSv} / \mathrm{y}$, and with an average of $6.158 \mathrm{mSv} / \mathrm{y}$ which were within the universal limit (3-10 mSv/y) [10] .Also in table(2), and figure(4), the values of LCR were ranged from 55.993 to 149.346 per million people, and with an average of 110.855 per million people who were within the universal limit (170-230 per million people) [11].At last, in table(2), it can be noticed that the values of EP were ranged from (0.550 to 1.466 )WLM/Y, and with an average (1.088WLM/Y) which were lower than the accepted universal limits (1-2 WLM/Y) [7]. All result in this study more than another study in Baghdad governorate [12].

\section{Conclusion}

Outcomes showed that the average of radon concentration with its risk parameters inside these locations in spite of they were lower than the acceptable universal limits but some of these locations had a high value of radon concentrations that can pose a risk of lung cancer 


\section{Ibn Al-Haitham Jour. for Pure \& Appl. Sci. 33 (4) 2020}

over time. also other sites had concentrations that could not be underestimated and should be continuously monitored to ensure safety of their workers. The results of radon health effects (AED, LCR and EP) were all within the acceptable limits given by ICRP, 2009. So, there was no cancer risk of radon in the two factories under study.

Table 1. Code, Room Name with it Details, Track Density and Radon Concentration

\begin{tabular}{|c|c|c|c|c|c|}
\hline No. & Code & Room name & $\begin{array}{l}\text { Room details } \\
(\text { LxWxH) }\end{array}$ & $\begin{array}{l}\text { Track density } \\
\left(\text { No. of tracks } / \mathbf{m m}^{2} \text { ) }\right.\end{array}$ & $\begin{array}{c}(\mathrm{CRn} \pm \mathrm{S.D}) \\
\mathrm{Bq} / \mathrm{m}^{3}\end{array}$ \\
\hline 1 & P1a & Workshope1 & $4 \times 3 \times 3$ & 1008.592 & $131.117 \pm 16.569$ \\
\hline 2 & P1b & Workshope2 & $4 \times 3 \times 3$ & 948.8077 & $123.345 \pm 12.788$ \\
\hline 3 & P1c & Generator room & $3 \times 3 \times 3$ & 2118.185 & $275.364 \pm 27.117$ \\
\hline 4 & P1d & Workshope3 & $4 \times 2 \times 3$ & 2530.654 & $328.985 \pm 46.074$ \\
\hline 5 & P1e & Workshope4 & $4 \times 2 \times 3$ & 2114.185 & $274.844 \pm 28.565$ \\
\hline 6 & P1f & CNC machine room & $20 \times 5 \times 3$ & 1965.615 & $255.53 \pm 26.727$ \\
\hline 7 & P1g & Office & $3 \times 1.5 \times 3$ & 2405.631 & $12.732 \pm 40.517$ \\
\hline 8 & $\mathrm{P} 2 \mathrm{a}$ & Workshop 1 & $4 \times 3 \times 2.5$ & 1902.054 & $247.267 \pm 27.608$ \\
\hline 9 & $\mathrm{P} 2 \mathrm{~b}$ & Workshope2 & $4 \times 3 \times 2.5$ & 1973.346 & $256.535 \pm 35.683$ \\
\hline 10 & P2c & Office & $2 \times 1.5 \times 2.5$ & 1924.777 & $250.221 \pm 27.583$ \\
\hline 11 & P2d & Workshope3 & $4 \times 3 \times 3$ & 1849.451 & $240.4286 \pm 29.41$ \\
\hline 12 & P2e & Workshope4 & $2.5 \times 4 \times 3$ & 1800 & $234 \pm 29.771$ \\
\hline
\end{tabular}

Table (2): Radon Concentration, and Lung Cancer Risk with two other Risks Parameters in the Two Factories

\begin{tabular}{|l|l|l|l|l|l|}
\hline No. & Code & $\mathbf{C R n}\left(\mathbf{B q} / \mathbf{m}^{3}\right)$ & AED $\mathbf{~ m S v} / \mathbf{y}$ & LCR/10 \\
& & & & & person \\
\hline 1 & P1a & 131.117 & 3.306 & 59.521 & \\
\hline 2 & P1b & 123.345 & 3.110 & 55.993 & 0.584 \\
\hline 3 & P1c & 275.364 & 6.944 & 125.004 & 0.550 \\
\hline 4 & P1d & 328.985 & 8.297 & 149.346 & 1.227 \\
\hline 5 & P1e & 274.844 & 6.931 & 124.768 & 1.4662 \\
\hline 6 & P1f & 255.53 & 6.444 & 116.000 & 1.225 \\
\hline 7 & P1g & 312.732 & 7.887 & 141.967 & 1.138 \\
\hline 8 & P2a & 247.267 & 6.236 & 112.249 & 1.393 \\
\hline 9 & P2b & 256.535 & 6.469 & 116.456 & 1.102 \\
\hline 10 & P2c & 250.221 & 6.310 & 113.590 & 1.143 \\
\hline 11 & P2d & 240.4286 & 6.063 & 109.144 & 1.115 \\
\hline 12 & P2e & 234 & 5.901 & 106.226 & 1.071 \\
\hline Average & $244.19 \pm 61.52$ & 6.158 & 110.855 & 1.042 \\
\hline Universal limit & $200-300$ & $3-10$ & $170-230$ & 1.088 \\
\hline
\end{tabular}


Ibn Al-Haitham Jour. for Pure \& Appl. Sci. 33 (4) 2020

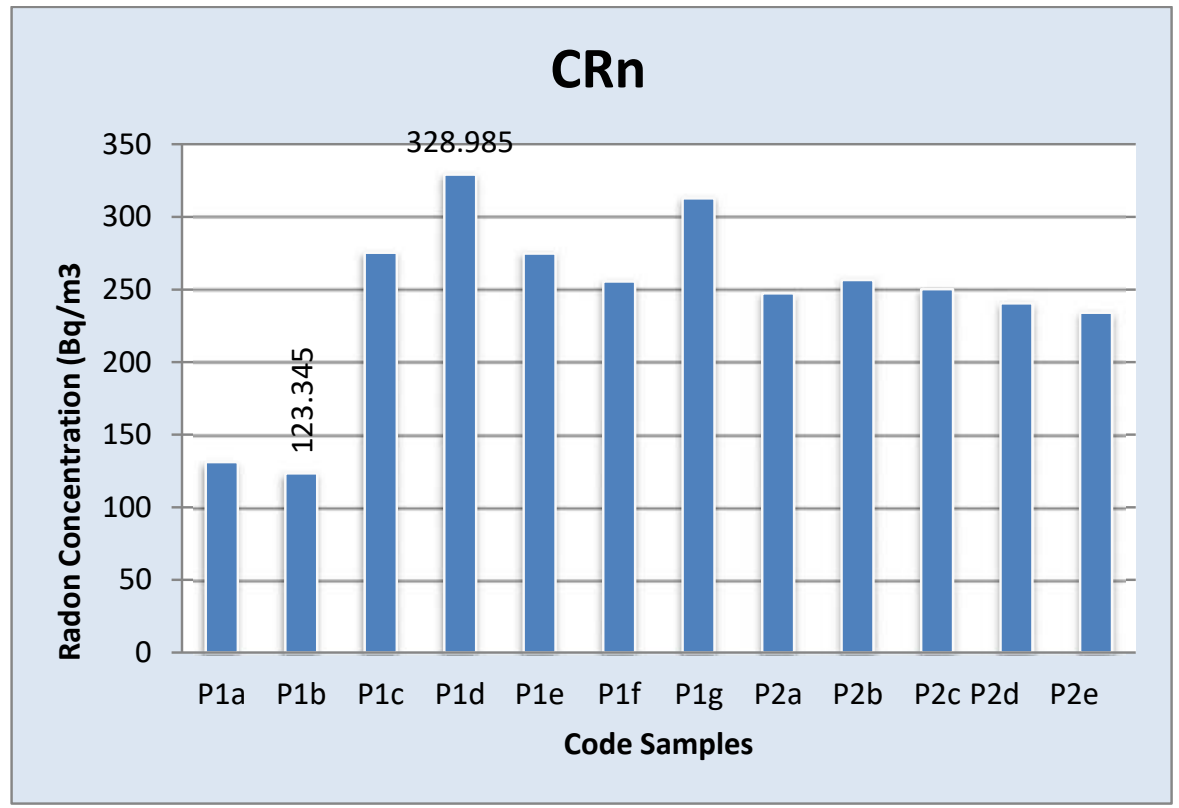

Figure 3, Radon Concentration inside the workshops

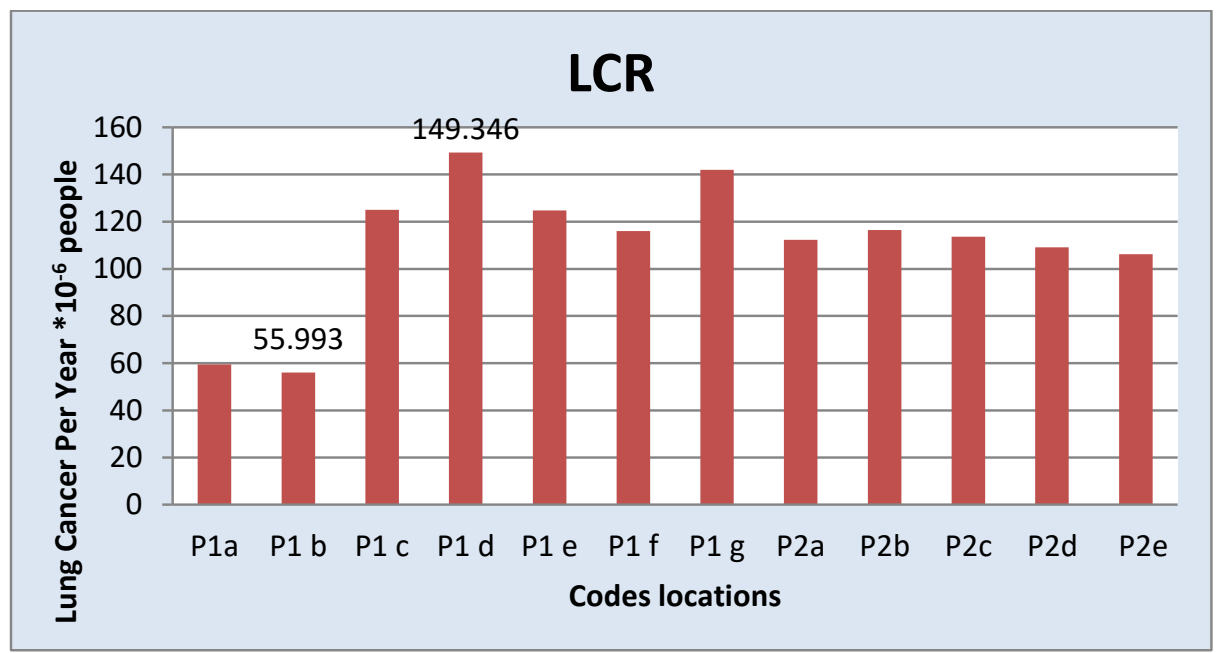

Figure 4, Lung Cancer per one year per million people (LCR) inside two factories

\section{Reference}

1. Landa, E. R. ; Gray, J. R. US Geological Survey research on the environmental fate of uranium mining and milling wastes. Environ. Geol.1995, 26, 19-31.

2. Ridha, A. A. Determination of Radionuclides Concentrations in Construction Materials Republic of Iraq Ministry of Higher Education College of Science Determination of Radionuclides Concentrations in Construction Materials Used in Iraq A thesis Submitted to the College. 2013. doi:10.13140/RG.2.1.3815.0640.

3. Akerblom, G. Naturally Occurring Radioactivity in the Nordic CountriesRecommendations. Radiat. Prot. Authorities Denmark, Finland, Iceland, Norw. Sweden 


\section{Ibn Al-Haitham Jour. for Pure \& Appl. Sci. 33 (4) 2020}

.2000, 50-64.

4. Wiegand, J. A guideline for the evaluation of the soil radon potential based on geogenic and anthropogenic parameters. Environ. Geol. 2001, 40, 949-963.

5. Ursulean, I.; Coreţchi, L.; Chiruţă; I. ; Vîrlan, S. Estimation of indoor radon concentrations in the air of residential houses and mines in the Republic of Moldova. in first east european radon symposium-feras 2012.

6. Barillon, R.; Klein, D.;Chambaudet, A.;Membrey, F. ; Fromm, M. Additional uses of polymeric nuclear track detectors (CR 39 and LR 115) for measuring radon emanation. Int. J. Radiat. Appl. Instrumentation. Part D. Nucl. Tracks Radiat. Meas. 1991, 19, 291-296.

7. Ismail, A. H. ; Jaafar, M. S. Indoor radon concentration and its health risks in selected locations in Iraqi Kurdistan using CR-39 NTDs. in 2010 4th International Conference on Bioinformatics and Biomedical Engineering 1-8 (IEEE, 2010).

8. Abdullah, A. A. Internal and external radiation exposure evaluation amongst selected workers and locations in Iraq. 2013

9. Lindell, B.; Dunster, H. J. ; Valentin, J. The International Commission on Radiological Protection at 90. Ann. ICRP.2018, 47, 343-345 .

10. International Commission on Radiological Protection. International Commission on Radiological Protection Statement on Radon. ICRP Ref 00/902/09 2009, 2 (2009).

11. Radiation; U. N. S. C. on the E. of A. Sources and Effects of Ionizing Radiation: United Nations Scientific Committee on the Effects of Atomic Radiation: UNSCEAR 1994 Report to the General Assembly, with Scientific Annexes. ,49 (United Nations Publications, 1994).

12. Najam, L. A.;Ebrahiem, S. A.; Abbas, S. A. ; Mahdi, H. A. Assessment of radon gas concentrations levels and radiation hazards in the dwellings of Baghdad province, Iraq. Rasayan J. Chem. 2018, 11, 37-40. 